\title{
Zwitterion Effect of Cow Brain Protein towards Efficiency Improvement of Dye-Sensitized Solar Cell (DSSC)
}

\author{
Denny Widhiyanuriyawan $\mathbb{D}^{1},{ }^{1}$ Prihanto Trihutomo $\mathbb{D}^{1,},{ }^{1,2}$ Sudjito Soeparman, ${ }^{1}$ \\ and Lilis Yuliati ${ }^{1}$ \\ ${ }^{1}$ Department of Mechanical Engineering, Brawijaya University, Jl. Veteran, Malang 65145, Indonesia \\ ${ }^{2}$ Department of Mechanical Engineering, State University of Malang, Jl. Semarang 5, Malang 65145, Indonesia
}

Correspondence should be addressed to Denny Widhiyanuriyawan; denny_w@ub.ac.id

Received 16 August 2019; Revised 16 December 2019; Accepted 9 January 2020; Published 19 February 2020

Academic Editor: Ho SoonMin

Copyright (c) 2020 Denny Widhiyanuriyawan et al. This is an open access article distributed under the Creative Commons Attribution License, which permits unrestricted use, distribution, and reproduction in any medium, provided the original work is properly cited.

\begin{abstract}
Dye-Sensitized Solar Cell (DSSC) constitutes a solar cell using natural dyes from plants that are adsorbed in semiconductors to convert solar energy into electrical energy. DSSC has relatively inexpensive fabrication costs, is easy to produce, works in visible light, and is environmentally friendly. The disadvantage of DSSC is that its efficiency is still low compared to silicon solar cells. This low efficiency is due to obstacles in the flow of electric current on DSSC. In this study, DSSC has been successfully fabricated with the deposition of clathrin protein from cow brain. The zwitterions effect of protein on cow brain is able to reduce resistance and increase electric current on DSSC. The zwitterions effect of cow brain protein that fills gaps or empty spaces between $\mathrm{TiO}_{2}$ particles generates acidic reactions (capturing electrons) and bases (releasing electrons); hence, proteins in the cow brain are able to function as electron bridges between $\mathrm{TiO}_{2}$ molecules and generate an increase in electric current in DSSC. The method used in this research was to deposit clathrin protein from cow brain in a porous $\mathrm{TiO}_{2}$ semiconductor with a concentration of $0 \%, 25 \%, 50 \%$, and $75 \%$. Tests carried out on DSSC that have been performed were X-Ray Diffractometer (XRD) testing to determine the crystal structure formed, Fourier Transform Infrared Spectroscopy (FTIR) testing to determine the functional groups formed on DSSC, Scanning Electron Microscopy (SEM) testing to determine the surface morphological characteristics of the DSSC layer, and testing the efficiency using AM $1.5 \mathrm{G}$ solar simulator $(1000 \mathrm{~W} / \mathrm{m} 2)$ to determine the efficiency changes that occur in DSSC. From the XRD test results by increasing the concentration of cow brain protein in DSSC, the structure of amino acid crystals also increased and the crystal size increased with the largest crystal size of $42.25 \mathrm{~nm}$ at the addition of $75 \%$ of cow brain protein. FTIR test results show that the addition of cow brain protein will form functional protein-forming amino groups on DSSC. FTIR analysis shows the sharp absorption of energy by protein functional groups in the FTIR spectrum with increasing concentration of cow brain protein in DSSC. The SEM test results show that the concentration of additional molecules of protein deposited into $\mathrm{TiO}_{2}$ increases and the cavity or pore between the $\mathrm{TiO}_{2}$ molecules decreases. The reduction of cavities in the layers indicates that protein molecules fill cavities that exist between $\mathrm{TiO}_{2}$ molecules. From the results of testing using AM $1.5 \mathrm{G}$ solar simulator $(1000 \mathrm{~W} / \mathrm{m} 2)$, the highest efficiency value is $1.465 \%$ with the addition of $75 \%$ brain protein concentration.
\end{abstract}

\section{Introduction}

The technical obstacle to the development of solar cells is the need for a single crystal silicon to generate solar cell panels to produce an efficiency of around 30\%. While producing single crystal silicon requires a high cost, hence it is not efficient as an alternative energy source. The low efficiency of solar cells causes the need for large amounts of solar panels to generate large amounts of power [1]. Another technical obstacle is the absorption spectrum that is too narrow from silicon-based solar cells. The main spectrum of absorption of silicon solar cells is ultraviolet and purple. It is known that the energy distribution from sunlight consists of about $7 \%$ of ultraviolet, $47 \%$ of visible light, and $46 \%$ of infrared. This shows that silicon solar cells cannot use almost $93 \%$ of the energy from sunlight [2]. 
To overcome this problem, a recent type of photochemical solar cell has been discovered, namely, Dye-Sensitized Solar Cell (DSSC), which is a type of solar cell exciton developed by O'Regan and Gratzel in 1991 [3].

Unlike conventional solar cells, DSSC is a photoelectrochemical solar cell that uses electrolytes as a charge transport medium. Besides electrolytes, DSSC is divided into several parts consisting of $\mathrm{TiO}_{2}$ nanopores, dye molecules adsorbed on the surface of $\mathrm{TiO} 2$, and carbon catalysts, which are all deposited between two Transparent Conductive Oxide (TCO) pieces of glass, as shown in Figure 1.

Some of the advantages offered by DSSC compared to other solar cell devices are, for instance, as follows: the fabrication costs are relatively inexpensive, it is easy to produce, it works in visible light, and it is environmentally friendly [4].

One of the most important DSSC components is a dye sensitizer, which is an electron pump driven by photos (light) from a DSSC device. This allows the injection of electrons into the semiconductor conduction band and the conversion of visible light photons into electricity. Dyes in DSSC act as absorbers of visible light or sensory photons; thus, the $\mathrm{TiO}_{2}$ semiconductor that only works in the UV region is able to work in the visible light region. Inorganic sensitizers in the form of synthetic transition metal complex dyes are reported to have good solar-to-electricity conversion efficiency [5]. Although it has been proven effective, the high cost of production $(>\$ 1000 / \mathrm{g})$, limited ingredients, and side effects caused by the environment become obstacles when it will be implemented on a large scale [6].

Organic compounds from nature can also be used as a sensitizer in DSSC. Organic compounds as sensory dyes are less expensive, easier to obtain and produce, and environmentally friendly. Natural plant pigments such as chlorophyll, carotene, and anthocyanin extracted from leaves, flowers, fruit, and skin are reported to be used as sensitizers in DSSC [7]. The use of chlorophyll as a natural dye in DSSC has been carried out by Arifin et al. [8]. Wang et al. conducted a study using chlorophyllin isolated from Undaria pinnatifida seaweed for use as a sensitizer on DSSC [9]. Table 1 shows the comparison of efficiency in DSSC using a variety of different natural dyes.

According to Table 1, DSSC using a variety of natural dyes obtains efficiencies ranging $0.03 \%-1.7 \%$.

Basically, the working principle of DSSC is the reaction of electron transfer (Figure 2). The first process begins with the occurrence of electron excitation in dye molecules due to absorption of photons (hv). Electrons are excited from ground state $(D)$ to excited state $\left(D^{*}\right)$. The electrons from the excited state are then directly injected into the titania conduction band (ECB); hence, the dye molecule is oxidized $\left(D^{+}\right)$. After reaching the TCO electrode, electrons flow into the counter electrode through an external circuit. In the presence of a catalyst at the counter electrode, electrons are received by the electrolyte; accordingly, the holes formed in the electrolyte $\left(\mathrm{I}_{3}^{-}\right)$, due to electron donors in the previous process, combine with electrons to form iodide $\left(\mathrm{I}^{-}\right)$. With the electron donor by electrolyte $\left(\mathrm{I}^{-}\right)$, the dye molecule returns to its initial state (ground state) and prevents the

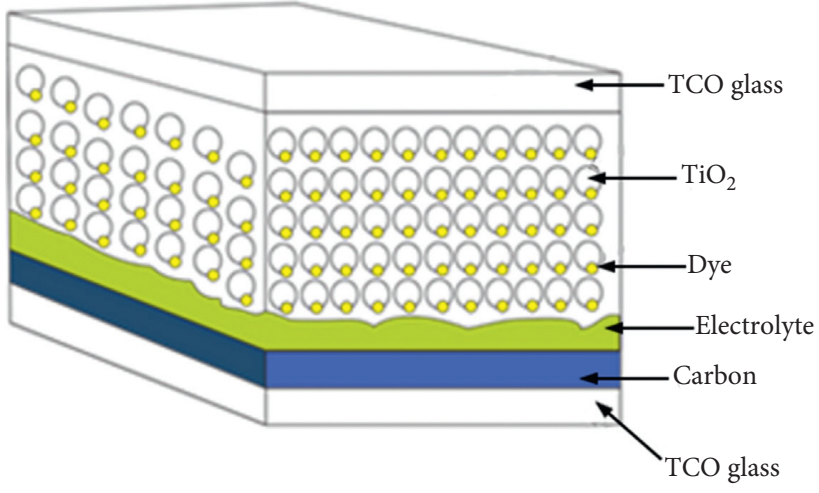

Figure 1: Dye-Sensitized Solar Cell structure [3].

recapture of electrons by the oxidized dye. This iodide is used to donate electrons to oxidized dyes, thus forming an electron transport cycle. With this cycle, there is a direct conversion from sunlight to electricity.

The working principle of DSSC if written in the form of an equation is as follows:

$$
\begin{aligned}
D+\mathrm{hv} & \longrightarrow D^{*}, \\
D^{*} & \longrightarrow D^{+}+\mathrm{e}^{-}, \\
\mathrm{I}_{3}^{-}+2 \mathrm{e}^{-} & \longrightarrow 3 \mathrm{I}^{-}, \\
2 D^{+}+3 \mathrm{I}^{-} & \longrightarrow \mathrm{I}_{3}^{-}+2 D .
\end{aligned}
$$

The main issue found in DSSC is lower efficiency than silicon solar cells [10]. This low efficiency is due to obstacles in the flow of electric current in DSSC. This obstacle is caused by suboptimal contact between semiconductor particles, because there is a gap or empty space between semiconductor particles. The existence of this gap or empty space causes the current flow to be hampered; accordingly, the DSSC efficiency is low [11].

In Figure 3, the flow of electron transport in the $\mathrm{TiO} 2$ layer, it appears that electrons are able to only flow through interconnected $\mathrm{TiO}_{2}$ particles because of porosity of $\mathrm{TiO}_{2}$ particles being able to pass through the gap or empty space [11]. This causes a decrease in DSSC efficiency.

Various attempts have been made to improve the efficiency of DSSC. Previous research has been done to improve efficiency by deposition or addition of nanosized particles to the structure of the semiconductor layer, for instance, by depositing Ag nanoparticles [12], doping Indium nanoparticles [13], adding bamboo charcoal powder particles to the $\mathrm{TiO} 2$ layer [14], and adding $\mathrm{Li}^{+}$particles [15].

One way to increase the flow of electric current and efficiency can be done by combining organic and inorganic elements in the DSSC structure. The organic element is in the form of clathrin protein from the brain of the cow while the inorganic element is the semiconductor $\mathrm{TiO}_{2}$.

Clathrin is a protein found in a cow brain that plays an important role in the formation of vesicle layers. Clathrin protein in bovine brain is used to build small vesicles to transport molecules in cells. Vesicles allow cells to communicate, transfer nutrients, import signaling receptors, mediate immune responses after taking extracellular 
TABle 1: Comparison of natural dye efficiency on DSSC [4].

\begin{tabular}{|c|c|c|c|c|}
\hline Dye & $\begin{array}{c}\text { Jsc } \\
\left(\mathrm{mAcm}^{2}\right)\end{array}$ & $\begin{array}{l}\text { Voc } \\
\text { (V) }\end{array}$ & $\mathrm{FF}$ & $\begin{array}{c}\eta \\
(\%)\end{array}$ \\
\hline Rosella & 1.63 & 0.4 & 0.57 & 0.37 \\
\hline Blue pea & 0.37 & 0.37 & 0.33 & 0.05 \\
\hline Mixed rosella-blue pea & 0.82 & 0.38 & 0.47 & 0.15 \\
\hline Black rice & 1.14 & 0.55 & 0.52 & \\
\hline Capsicurn & 0.23 & 0.41 & 0.63 & \\
\hline Rosa xanthina & 0.64 & 0.49 & 0.52 & \\
\hline Kelp & 0.43 & 0.44 & 0.62 & \\
\hline Erythrina variegata & 0.78 & 0.48 & 0.55 & \\
\hline Bixin & 1.1 & 0.57 & 0.59 & 0.37 \\
\hline Annatto & 0.53 & 0.56 & 0.66 & 0.19 \\
\hline Norbixin & 0.38 & 0.53 & 0.64 & 0.13 \\
\hline Crocetin & 2.84 & 0.43 & 0.46 & 0.56 \\
\hline Crocin & 0.45 & 0.58 & 0.6 & 0.16 \\
\hline Fruit of calafate & 6.2 & 0.47 & 0.36 & \\
\hline Syrup of calafate & 1.5 & 0.38 & 0.2 & \\
\hline Skin of jaboticaba & 7.2 & 0.59 & 0.54 & \\
\hline Red Sicilian orange & 3.84 & 0.34 & 0.5 & \\
\hline Purple eggplant extract & 3.4 & 0.35 & 0.4 & \\
\hline Dragon fruit & 0.2 & 0.22 & 0.3 & 0.22 \\
\hline Pomegranate juice & 0.2 & 0.4 & 0.45 & 1.5 \\
\hline Red turnip & 9.5 & 0.43 & 0.37 & 1.7 \\
\hline Wild Sicilian prickly pear & 8.2 & 0.38 & 0.38 & 1.19 \\
\hline Sicilian Indian fig & 2.7 & 0.38 & 0.54 & 0.5 \\
\hline Bougainvillea & 2.1 & 0.3 & 0.57 & 0.36 \\
\hline Shisonin & 3.56 & 0.55 & 0.51 & 1.01 \\
\hline Shisonin and chlorophyll & 4.8 & 0.53 & 0.51 & 1.31 \\
\hline Chlorophyll & 3.52 & 0.43 & 0.39 & 0.59 \\
\hline Hibiscus surattensis & 5.45 & 0.39 & 0.54 & 1.14 \\
\hline Sesbania grandiflora & 4.4 & 0.41 & 0.57 & 1.02 \\
\hline Hibiscus rosa-sinensis & 4.04 & 0.4 & 0.63 & 1.02 \\
\hline Nerium oleander & 2.46 & 0.41 & 0.59 & 0.59 \\
\hline Ixora macrothyrsa & 1.31 & 0.4 & 0.57 & 0.3 \\
\hline $\begin{array}{l}\text { Rhododendron arboreum } \\
\text { zeylanium }\end{array}$ & 1.15 & 0.4 & 0.64 & 0.29 \\
\hline Begonia & 0.63 & 0.54 & 0.72 & 0.24 \\
\hline Tangerine peel & 0.74 & 0.59 & 0.63 & 0.28 \\
\hline Rhododendron & 1.61 & 0.59 & 0.61 & 0.57 \\
\hline Fructus lycii & 0.53 & 0.69 & 0.47 & 0.17 \\
\hline Marigold & 0.51 & 0.54 & 0.83 & 0.23 \\
\hline Perilla & 1.36 & 0.52 & 0.7 & 0.5 \\
\hline Herba artemisiae scopariae & 1.03 & 0.48 & 0.68 & 0.34 \\
\hline China loropetal & 0.84 & 0.52 & 0.63 & 0.27 \\
\hline Yellow rose & 0.74 & 0.61 & 0.57 & 0.26 \\
\hline Flowery knotweed & 0.6 & 0.55 & 0.63 & 0.21 \\
\hline Bauhinia tree & 0.96 & 0.57 & 0.66 & 0.36 \\
\hline Petunia & 0.85 & 0.62 & 0.61 & 0.32 \\
\hline Lithospermum & 0.14 & 0.34 & 0.59 & 0.03 \\
\hline Violet & 1.02 & 0.5 & 0.65 & 0.33 \\
\hline Chinese rose & 0.9 & 0.48 & 0.62 & 0.27 \\
\hline Mangosteen pericarp & 2.69 & 0.67 & 0.63 & 1.17 \\
\hline Rose & 0.97 & 0.6 & 0.66 & 0.38 \\
\hline Lily & 0.51 & 0.5 & 0.67 & 0.17 \\
\hline Coffee & 0.85 & 0.56 & 0.69 & 0.33 \\
\hline Broadleaf holly leaf base & 1.19 & 0.61 & 0.65 & 0.47 \\
\hline Red Bougainvillea glabra & 2.34 & 0.26 & 0.74 & 0.45 \\
\hline Violet Bougainvillea glabra & 1.86 & 0.23 & 0.71 & 0.31 \\
\hline Red Bougainvillea spectabilis & 2.29 & 0.28 & 0.76 & 0.48 \\
\hline $\begin{array}{l}\text { Violet Bougainvillea } \\
\text { spectabilis }\end{array}$ & 1.88 & 0.25 & 0.73 & 0.35 \\
\hline
\end{tabular}

TABle 1: Continued.

\begin{tabular}{lcccc}
\hline Dye & $\begin{array}{c}\mathrm{Jsc} \\
\left(\mathrm{mAcm}^{2}\right)\end{array}$ & $\begin{array}{c}\text { Voc } \\
(\mathrm{V})\end{array}$ & FF & $\begin{array}{c}\eta \\
(\%)\end{array}$ \\
\hline Spinach & 0.47 & 0.55 & 0.51 & 0.13 \\
Ipomea & 0.91 & 0.54 & 0.56 & 0.28 \\
Bougainvillea brasiliensis & 5 & 0.25 & 0.36 & 0.45 \\
Garcinia subelliptica & 6.48 & 0.32 & 0.33 & 0.69 \\
Ficus spathacea & 7.85 & 0.52 & 0.29 & 1.18 \\
Rhoeo spathacea & 10.9 & 0.5 & 0.27 & 1.49 \\
\hline
\end{tabular}

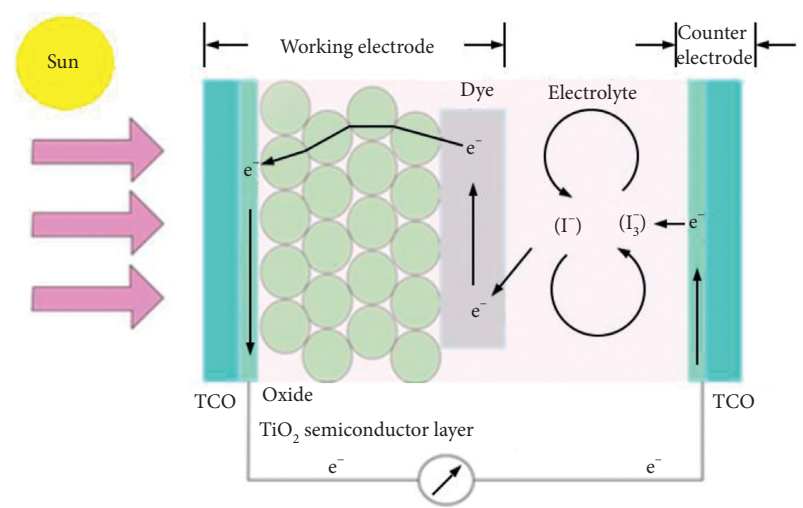

FIgURE 2: Working scheme of DSSC [3].

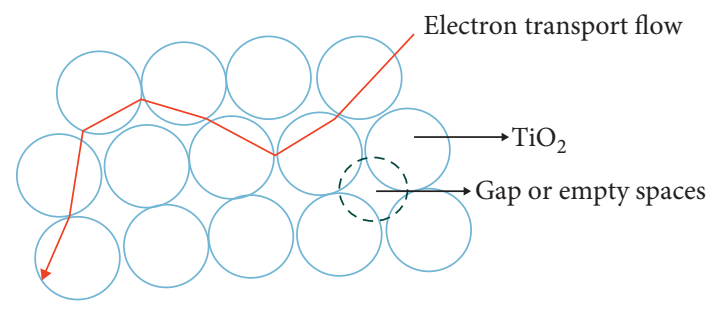

Figure 3: Gap or empty space between $\mathrm{TiO}_{2}$ [11]

samples, and clean up cell debris left behind by tissue inflammation.

The clathrin protein is shaped like a tripod: three leg spindles joined together on a hub or shaft. The shape of the triskelion consists of three clathrin heavy chains and three light chains. Clathrin molecules easily combine with each other to form a kind of honeycomb, similar to a lattice or net on the cell surface. When the triskelia interacts, they form a polyhedral lattice that surrounds the vesicle. Clathrin triskelion consists of three clathrin heavy chains, and each heavy chain weighing $180 \mathrm{kDa}$ has a light chain of $\sim 30 \mathrm{kDa}$ tightly bound to it. The three heavy chains provide the backbone or structural framework of the clathrin lattice, and the three light chains regulate the formation and dismantling of the clathrin lattice. When a great number of triskelia are connected, they form a basket-like structure. The clathrin combination structure is shown in Figure 4(b), built of 36 triskelia. The combination of the clathrin lattice is formed with sizes ranging $30-100 \mathrm{~nm}$ from about 36 clathrin molecular units consisting of 108 clathrin heavy chains and 108 clathrin light chains. When the right molecule attaches to the clathrin, the lattice structure of the clathrin will wrap it into a 


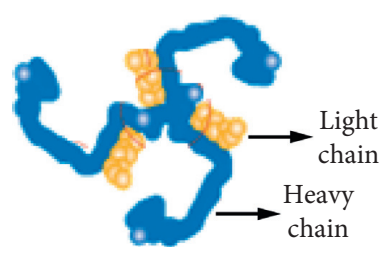

(a)

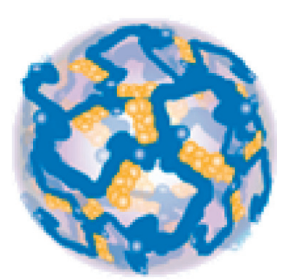

(b)

Figure 4: Clathrin protein [17]. (a) Single clathrin. (b) Combined clathrin.

sac-like shape. This clathrin sac carries the molecule to its intended destination [16].

Clathrin protein derived from cow brain has been applied to various materials as a biotech substrate. Materials that have been successfully added to clathrin are graphene, polymers, glass, and metals [18]. From Schoen's research, it is known that clathrin is able to bond with titanium dioxide. Titanium dioxide is a semiconductor material in a DSSC [19]. Clathrin plays an important role in the cell transport system; to be able to transport, clathrin cells must be able to bind to ions. Examples of ions that are able to bind to clathrin are positive ions in iron [20].

This study aims to determine the effect of clathrin protein derived from cow brain in increasing efficiency of DSSC. In this research, clathrin protein from cow brain will be added to the DSSC which will cover the $\mathrm{TiO}_{2}$ layer and dye; therefore, it fills gaps or empty spaces in the $\mathrm{TiO}_{2}$ semiconductor layer resulting in better contact between $\mathrm{TiO}_{2}$ particles and electron transfer to a maximum because it can pass through all parts of $\mathrm{TiO}_{2}$ semiconductor. The addition of cow brain protein is expected to increase efficiency in DSSC.

\section{Research Methodology}

This study employed an experimental method to test the effect of the addition of cow brain protein on increased efficiency in the DSSC. The research procedure was carried out by preparing material and equipment to be used in this study, then DSSC assembly was carried out, and then testing of DSSC was made. The material preparation needed was to prepare protein from the cow brain (clathrin protein), $\mathrm{TiO}_{2}$ paste, dye solution, electrolyte solution, carbon counter electrode, and TCO glass. Furthermore, the following was equipment prepared: i.e., Becker glass, measuring tubes, pipettes, magnetic stirrers, petri dishes, Whatman filter paper, furnaces, digital scales, mortars, scotch tapes, multimeters, solar simulators, solar power meters, electrophoresis apparatus, and centrifuges.

Then, the assembly was carried out with the following steps: giving $\mathrm{TiO}_{2}$ paste to the electrode glass, heating glass $/ \mathrm{TiO}_{2}$, soaking the dye, giving cow brain protein, giving electrolytes, giving carbon to the electrode counter, and then DSSC assembling. After the DSSC was assembled, tests which include XRD testing, FTIR testing, SEM testing, and efficiency testing in the solar simulator were performed.
Clathrin protein was obtained from protein isolation of a cow brain carried out in Biochemistry Laboratory of Universitas Brawijaya. The steps of protein isolation and making a protein profile with SDS-PAGE from cow brain tissue were as follows: doing homogenization of $300 \mathrm{mg}$ of cow brain samples and then sonification for about 10 minutes. The next step was centrifuging on $6000 \mathrm{rpm}$ for 15 minutes to get supernatant layer on top and its sediment at the bottom layer. After separating the supernatant from sediment, then supernatant was added with ethanol in a volume ratio of $1: 1$. Ethanol was added to the uppermost layer containing plasmids and left to form sediment at $-20^{\circ} \mathrm{C}$. The next step was to recentrifuging at $10000 \mathrm{rpm}$ and obtain pellets in very small amounts. Then, Tris- $\mathrm{HCl}$ solvent was added with a volume ratio of $1: 1$ which serves to maintain the $\mathrm{pH}$ of the solution. The next step was to do protein profiles with Sodium Dodecyl Sulfate-Polyacrylamide Gel Electrophoresis (SDS-PAGE) technique which is a small-scale purification technique that results in the separation of a protein based on its molecular weight in specific bands that appear on polyacrylamide gels. After the protein profile process, then sample was immersed in a distaining solution while shaking using a shaker until the bands on the gel is clearly visible. The bands in the electrophoresis gel were determined by their respective Retention factor value ( $\mathrm{Rf}$ value) and relative molecular masses and then recorded in the form of data.

$\mathrm{TiO}_{2}$ paste was made as follows: Polyvinyl Alcohol (PVA) of 1.5 grams was added to $13.5 \mathrm{ml}$ of distilled water, and then it stirred with a rotary motor at a temperature of $80^{\circ} \mathrm{C}$ for \pm 30 minutes until the solution thickens. This suspension functioned as a binder in making paste. Add the suspension to 0.5 grams of $\mathrm{TiO}_{2}$ powder which is about $7.5 \mathrm{ml}$. $\mathrm{TiO}_{2}$ powder used is titanium dioxide anatase from Sigma-Aldrich. Then, a mixture of suspension and $\mathrm{TiO}_{2}$ powder was crushed by a mortar to form a good paste to be coated. The optimal degree of viscosity of the paste was obtained by adjusting the number of binders and also if necessary water was added to the mixture of binder and $\mathrm{TiO}_{2}$ powder.

Electrolyte was prepared as follows: electrolyte solution was made by dissolving a mixture of 0.8 grams $(0.5 \mathrm{M})$ of potassium iodide (KI) into $10 \mathrm{ml}$ of PEG 400 and then stirring evenly. Furthermore, 0.127 grams $(0.05 \mathrm{M})$ of iodine $\left(\mathrm{I}_{2}\right)$ was added to the solution and stirred until all three ingredients were completely dissolved. The ready-to-use electrolyte solution was temporarily stored in an enclosed dark bottle. 
The dye was prepared as follows: 100 grams of papaya leaves with acetone ProAnalysis (P.A) $500 \mathrm{ml}(\mathrm{w} / \mathrm{v})$ solvent was prepared for extraction. The papaya leaves were firstly cleaned and drained. Next, the leaves were cut into small pieces and blended until they were smooth. The finer the papaya leaves, the better the extraction process. Papaya leaves that have been refined were then mixed with $500 \mathrm{ml}$ acetone P.A into a Becker glass. Furthermore, it was stirred using a rotary motor for 30 minutes; thus, the chlorophyll was separated from the leaves, until the acetone P.A solution turned into green and the leaves turned into white. Then, the contents of the glass were filtered using gauze paper (Whatman) to separate the solution with leaf pulp. Consequently, we obtained a $500 \mathrm{ml}$ dye from the papaya leaf. After that, the dye was kept in a tightly closed dark bottle to avoid decomposition and light which reduce the absorption of the dye.

Hereinafter, carbon counter electrodes were composed as follows: one of the TCO glass substrates which acts as a counter electrode was burned using a candle flame until the soot filled the conductive area of the substrate. This combustion process coated the substrate with carbon (carbon counter electrodes). This carbon served as a catalyst in DSSC. The catalyst was needed to accelerate the reaction kinetics of the triiodide reduction process on TCO.

The following procedure explains DSSC assembly: on the conductive TCO glass that has been cut into $1.5 \times 1.5 \mathrm{~cm}^{2}$ where $\mathrm{TiO}_{2}$ was deposited by scotch tape on the side of the glass that has resistivity, thus, it formed $1 \times 1 \mathrm{~cm}$ area. Scotch tape was also used to control the thickness of $\mathrm{TiO}_{2}$ paste. To thicken the paste on the glass surface, scotch tape can be stacked in layers according to the needs.

$\mathrm{TiO}_{2}$ paste was deposited over the area that has been made on the conductive glass by the doctor blade method, with the aid of a stirring rod to flatten the $\mathrm{TiO}_{2}$ paste on the substrate starting from the end of the frame. Then, the conductive transparent glass coated with $\mathrm{TiO}_{2}$ paste was dried in a furnace at $450^{\circ} \mathrm{C}$ for 30 minutes. This process aims to grow porosity and form a good adhesive contact between the solution and the TCO glass substrate.

Conductive glass has been deposited with $\mathrm{TiO}_{2}$ paste and has been heated and then immersed in a dye solution for approximately 24 hours, and then the $\mathrm{TiO}_{2}$ layer on the conductive glass turned into green. In this process, chlorophyll adsorption occurred on the surface of $\mathrm{TiO}_{2}$.

Furthermore, cow brain protein solution was added to the layer of $\mathrm{TiO}_{2}$ and dye with varying concentrations of $25 \%, 50 \%$, and $75 \%$ to $\mathrm{TiO}_{2}$. Then, the electrolyte solution was dripped on a layer of $\mathrm{TiO}_{2} /$ dye/cow brain protein.

The final step in manufacturing DSSC was to unite the two substrates. The counter electrode which has been given a carbon catalyst was then placed on a layer of $\mathrm{TiO}_{2} /$ dye/cow brain protein/electrolyte with a sandwich structure where each tip was offset by $0.5 \mathrm{~cm}$ for electrical contact. Then, the cell structure was firmly clamped with binder clips on both sides. DSSC solar cells were ready to be tested.

Tests carried out on DSSC were XRD testing to determine the crystal structure and crystal size, FTIR testing to determine the functional groups formed on DSSC, SEM testing to determine the surface morphological characteristics of the DSSC layer, and testing electric current and voltage to determine the changes in efficiency that occurred in DSSC.

Electric current and voltage on DSSC were generated by lighting using halogen lamps in a solar simulator, and then the change in current and voltage produced was measured using a data logger to determine DSSC performance. Schematically, the research installation is as follows.

It consisted of a solar simulator to provide lighting to DSSC to produce current and voltage to be measured to determine DSSC performance as shown in Figure 5. The solar simulator has a length of $300 \mathrm{~mm}$, width of $300 \mathrm{~mm}$, and height of $500 \mathrm{~mm}$. The equipment in the solar simulator is a $1000 \mathrm{~W} / \mathrm{m}^{2}$ intensity halogen lamp to provide lighting, UV and IR filters to produce visible light, temperature sensors, intensity sensors, and fans that function to maintain a constant temperature. Current and voltage data generated in DSSC were measured using the Arduino Uno ATmega 328 data logger microcontroller.

The stages of data collection are as follows: the equipment was set according to Figure 5. Then, DSSC was placed in the middle with the distance to the lighting regulated; thus, the intensity was $1000 \mathrm{~W} / \mathrm{m}^{2}$. Then, the lights were turned on; accordingly, current and voltage emerged from DSSC. DSSC varied the percentage of clathrin protein content in $\mathrm{TiO}_{2}$, namely, $0 \%, 25 \%, 50 \%$, and $75 \%$. Current and voltage data obtained were then transferred to a computer to calculate its efficiency (it followed the method suggested by Trihutomo et al.) [21].

\section{Results and Discussion}

3.1. XRD Testing. X-Ray Diffractometer (XRD) testing was used to determine the crystal structure formed and grain size in the $\mathrm{TiO}_{2}$ layer doped with cow brain protein. The XRD test results in the form of a diffraction pattern (diffractogram) consisting of characteristic peaks for each concentration of protein addition on $\mathrm{TiO}_{2}$ are presented in Figure 6 .

Based on Figure 6, it appears that the peaks formed from the crystal structure are sharp because they have a high degree of orderliness, whereas in amorphous, the peaks generated were very gentle slopes since they have a very low degree of order.

In Figure 6(a), based on reference code 01-073-1764 from the International Center for Diffraction Database (ICDD) data, the crystal structure formed was $\mathrm{TiO}_{2}$ type anatase. The use of anatase phase $\mathrm{TiO}_{2}$ nanoparticles in DSSC has the potential to achieve higher efficiency in converting light into electricity because it has a high photoactive ability. In Figures 6(b)-6(d), with the addition of protein to $\mathrm{TiO}_{2}$, based on reference code 00-049-2369, the crystalline structure of amino acid hydrate $(\mathrm{C} 12 \mathrm{H} 15 \mathrm{NO} 3 \mathrm{H} 20)$ appears in intensity which increases with increasing concentration of cow brain protein. The appearance of the amino acid crystal structure indicates the successful synthesis of cow brain protein in $\mathrm{TiO}_{2}$. The presence of amino acids in the DSSC structure increases the conductance of electric current in the DSSC layer since amino acids are electrolyte. This is because amino acids have a 


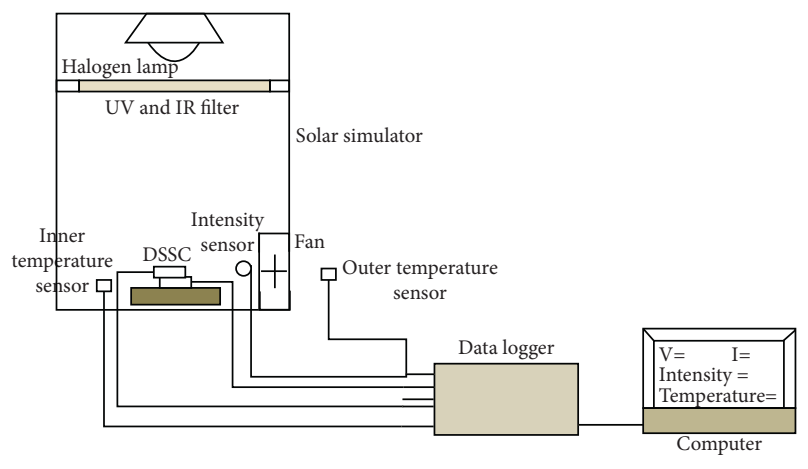

FIGURE 5: Research instrument installation.

structure that tends to be charged and has a high polarity. Increasing the electric current will increase efficiency on DSSC. Amino acids have the ability as zwitterions, a molecule that contains both a carboxylic group (acidic) and an amine group (basic). By having the zwitterions capability, amino acids simultaneously contain negative ions and positive ions in the molecule. Electrons will be captured by amino acid molecules when an acid reaction occurs and electrons will be released by amino acid molecules when a base reaction occurs [22]. Efficiency increased in DSSC because amino acids in cow brain proteins can act as electron bridges between porous $\mathrm{TiO}_{2}$ molecules so that electron transfer is faster and reduces recombination due to the effects of zwitterions contained in cow brain proteins.

The XRD test results shown in Figures 6(a)-6(d) in the peak position area (marked with a square) show the intensity of the diffraction peak that are getting higher and firmer with the addition of $25 \%, 50 \%$, and $75 \%$ protein concentrations in $\mathrm{TiO}_{2}$. With the higher intensity due to the addition of clathrin protein, the degree of crystallinity of the sample is better. With a good degree of crystallinity, the electron diffusion process in $\mathrm{TiO}_{2}$ will be faster which implies that the electron transfer process for DSSC as a whole will be higher; hence, it will increase the efficiency of solar cells. It is clear from Figures 6(b)-6(d) in the peak position area that after adding clathrin protein the count or intensity of diffractogram pattern is higher than Figure 6(a) without clathrin protein; this indicates the growth of crystallites due to the addition of clathrin protein on $\mathrm{TiO}_{2}$.

The growth of crystallites causes a better degree of crystallinity so that the electron transfer is better and increases the efficiency of DSSC [23]. The increase in intensity due to the addition of clathrin can also be proven from the Full Width at Half Maximum (FWHM) value. Based on Table 2, with increasing clathrin concentration, it appears that the FWHM value is getting smaller. The smaller FWHM value associated with a sharper diffraction peak or higher diffraction intensity (marked with a square) indicates the growth of crystals so that the degree of crystallinity is getting better [24].

The diffractogram pattern obtained from XRD data can also be used to determine the size of the crystals formed based on the FWHM values at various peak position using

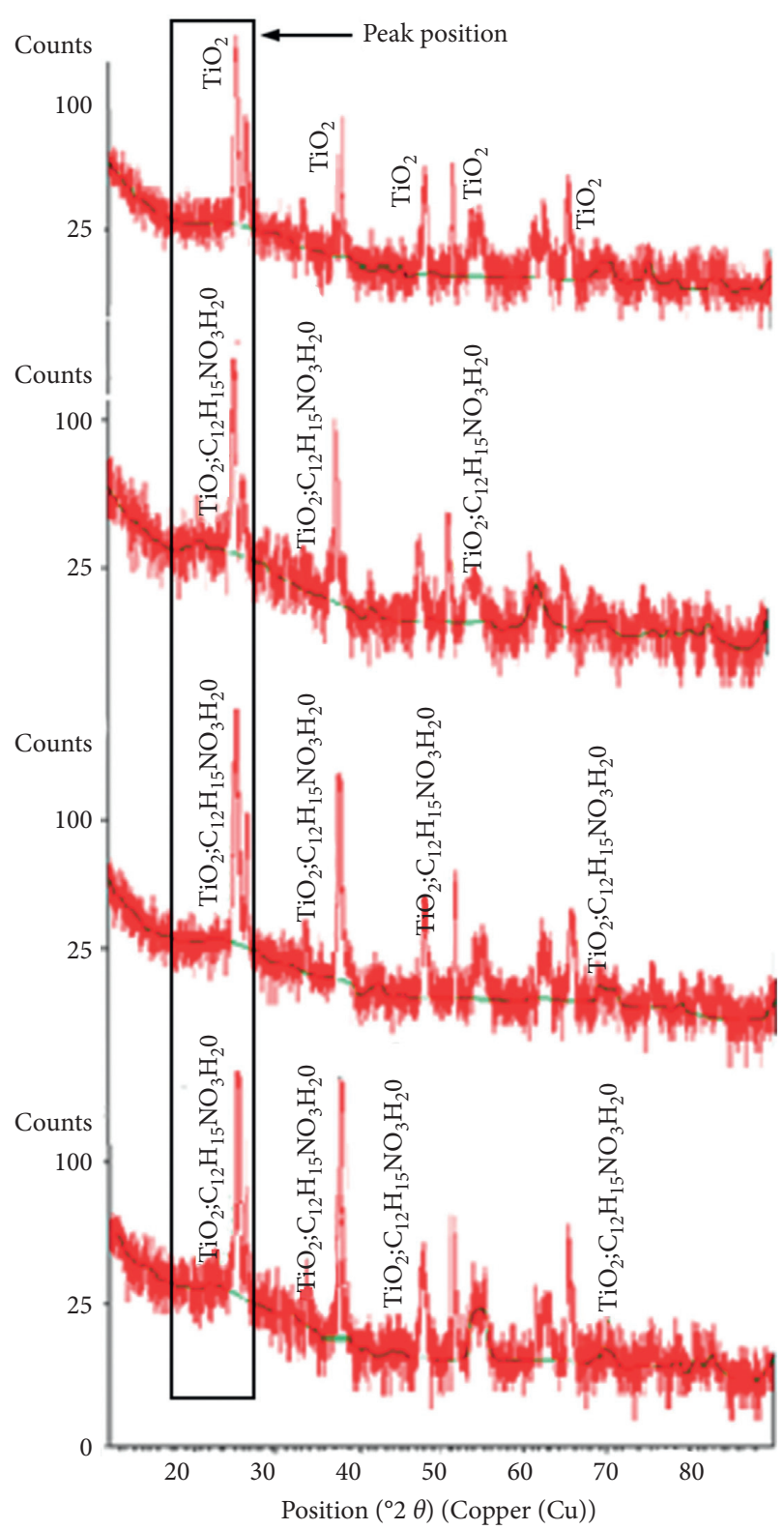

FIgURE 6: Diffractogram XRD test results for each cow brain protein concentration (\%) (a) 0, (b) 25, (c) 50, and (d) 75 .

Table 2: Crystal Structure Peak and Crystal Size Data for each concentration of protein clathrin addition on $\mathrm{TiO}_{2}$.

\begin{tabular}{lccc}
\hline $\begin{array}{l}\text { Clathrin } \\
(\%)\end{array}$ & $\begin{array}{c}\text { Peak position } \\
\left({ }^{\circ} 2 \theta\right)\end{array}$ & $\begin{array}{c}\text { FWHM } \\
(\text { radian})\end{array}$ & $\begin{array}{c}\text { Crystal size } \\
(\mathrm{nm})\end{array}$ \\
\hline 0 & 25.22 & 0.0062 & 24.17 \\
25 & 25.18 & 0.0055 & 26.35 \\
50 & 25.31 & 0.0048 & 30.15 \\
75 & 25.09 & 0.0034 & 42.25 \\
\hline
\end{tabular}

the Scherrer equation, $D=(k \cdot \lambda) / \beta \cos \theta$, where $D$ is the size of the crystal, $\lambda=0.154 \mathrm{~nm}$ is the wavelength of X-rays, $\beta$ is the FWHM value of each characteristic peak position, $\theta$ is the diffraction angle of peak position, and $k \approx 0.94$ is a constant. 
The peak position of the diffractogram pattern is determined in the area marked by the squares (Figure 6) because it has the highest intensity which indicates the best degree of crystallinity. The $x$-axis on the diffractogram states the diffraction angle position $\left({ }^{\circ} 2 \theta\right)$ which functions to determine the phase of the material formed. The $y$-axis on the diffractogram states the amount of intensity from the diffraction angle of the material phase; the higher intensity indicates better degree of crystallinity of the material.

From Table 2, it is known that at peak position $\left({ }^{\circ} 2 \theta\right)$ for each concentration of clathrin protein addition the FWHM value decreases with increasing clathrin concentration. The smaller FWHM value is related to the sharper diffraction peaks produced. The sharper diffraction peaks produced are related to the smaller FWHM. As it is known that the smaller FWHM indicates an increase in crystallinity characterized by crystallite growth [24], the growth of this crystallite can be represented by the size of the crystallite produced in each sample. Thus, the crystallinity of titania with the addition of clathrin in this sample group (25\%, 50\%, and $75 \%)$ increases with increasing clathrin concentration. This analysis is also strengthened by the results of large crystallite calculations using the Scherrer equation. The estimated results of the sample size calculation of crystallites are $0 \%, 25 \%, 50 \%$, and $75 \%$ based on the Scherrer equation as explained in Table 2.

From Table 2, it appears that at peak position $\left({ }^{\circ} 2 \theta\right)$ for each concentration the addition of clathrin protein is known with the increasing percentage of cow brain protein in $\mathrm{TiO}_{2}$ leading to the increase of crystal size. The greater size of the crystals indicates the incorporation of cow brain protein molecules in the $\mathrm{TiO}_{2}$ molecule. The larger crystal size affects the distance of the atoms in the crystal that are increasingly close altogether resulting in a smaller lattice strain between molecules; accordingly, the internal resistance to the flow of electrons between molecules is also reduced [25].

\subsection{FTIR Testing. Fourier Transform Infrared Spectroscopy} (FTIR) testing was used to determine the functional groups formed in the DSSC layer due to the addition of cow brain protein. FTIR test results for each concentration of cow brain addition on $\mathrm{TiO}_{2}$ can be seen in Figure 7 .

From the results of the FTIR testing shown in Figure 7, it appears that the greater concentration of cow brain protein on DSSC shows the steeper absorption at the transmittance rate of the wave numbers in the FTIR spectrum. With the steeper uptake, the greater energy was absorbed by the functional group formed by the increasing concentration of cow brain protein in DSSC.

Based on the results of FTIR testing that have been carried out, it can be seen that the functional groups were formed. The results of FTIR testing showed peaks appearing in the wave number $500-900 \mathrm{~cm}^{-1}$ indicating the presence of $\mathrm{TiO}_{2}$ groups at all clathrin protein concentrations, peaks appearing in wave numbers of $1050-1150 \mathrm{~cm}^{-1}$ in samples of $\mathrm{TiO}_{2}+50 \%$ cow brain protein, $\mathrm{TiO}_{2}+75 \%$ cow brain protein showing the presence of $\mathrm{CO}$ Alcohol/Carboxylic Acid groups, peaks appearing in the wave number 1500-1570 $\mathrm{cm}^{-1}$ in samples of $\mathrm{TiO}_{2}+25 \%$ cow brain protein,
$\mathrm{TiO}_{2}+50 \%$ cow brain protein, $\mathrm{TiO}_{2}+75 \%$ cow brain protein showing the NO2 group of Nitro compounds, peak appearing at wave numbers $1500-1600 \mathrm{~cm}^{-1}$ at samples of $\mathrm{TiO}_{2}+25 \%$ cow brain protein, $\mathrm{TiO}_{2}+50 \%$ cow brain protein, and $\mathrm{TiO}_{2}+75 \%$ cow brain protein showing the presence of $\mathrm{C}=\mathrm{C}$ Aromatic Ring groups, peaks appearing in the wave number $1610-1680 \mathrm{~cm}^{-1}$ indicating the presence of $\mathrm{C}=$ groups C. Alkene, peaks appearing at wave numbers $2500-3600 \mathrm{~cm}^{-1}$ indicating the presence of $\mathrm{OH}$ groups Hydrogen bonding, and peaks appearing at wave numbers $3300-3500 \mathrm{~cm}^{-1}$ indicating the presence of $\mathrm{NH}$ Amine/ Amide groups [26]. The formation of functional groups in DSSC are N-H compounds amine, $\mathrm{O}-\mathrm{H}$, alkene, aromatic, NO-nitro compounds, and C-O alcohol/carboxylic acid that show functional groups of elements of amino acids so that they also form proteins [27].

From the results of the FTIR testing in Figures 7(b)-7(d), it appears that the higher the concentration of clathrin on $\mathrm{TiO}_{2}$, the sharper the uptake that occurred in the FTIR spectrum wave numbers for the protein constituent groups. The sharper uptake intensity indicates the higher structure or functional groups of amino acids formed and indicates the greater energy absorbed by the functional groups formed from the greater increase in the concentration of clathrin protein in DSSC [28].

Amino acids which simultaneously contain amine groups and carboxylic groups can be seen to have the ability as zwitterion. Zwitterion has the ability of molecules that have simultaneously negative ions and positive ions in the molecule. Zwitterion has the ability to do both acid and base reactions in its molecules [22]. When an acid reaction occurs, the molecule will capture electrons and when a base reaction occurs the molecule will release electrons. The zwitterion effect of the clathrin protein from cow brains provides the ability to transfer electrons and increase efficiency in DSSC.

\subsection{SEM Testing. SEM (Scanning Electron Microscopy)} analysis aims to determine the surface morphological characteristics of the DSSC layer. Figures $8(a)-8(d)$ show a DSSC morphology with a variation of the percentage of clathrin to $\mathrm{TiO} 2$, i.e., $0 \%, 25 \%, 50 \%$, and $75 \%$ SEM analysis results with magnification of 5000x.

Figure 8 shows SEM image with a magnification scale of 5000x of TiO2 nanomaterials that has been coated on FTO glass; it appears that the surface of this thin layer is not flat with the presence of light and dark parts, where the light part is coated with $\mathrm{TiO}_{2} /$ clathrin/dye layers while the dark parts are a cavity or gap that is not covered by a layer and are between the $\mathrm{TiO}_{2}$ /clathrin/dye layers.

Figure 8 (a) shows that the surface of the $\mathrm{TiO} 2$ thin film is hollow or porous. In the figure, it appears that there are still many cavities between $\mathrm{TiO}_{2}$ molecules that are marked with a lot of dark areas. Cavities in this thin layer function for adsorption of dye molecules in $\mathrm{TiO}_{2}$ [29]. But the presence of these cavities causes the transfer of electrons between $\mathrm{TiO}_{2}$ molecules to be inhibited, and this causes DSSC performance to be low. From the SEM test results, Figures $8(\mathrm{~b})-8(\mathrm{~d})$ show 


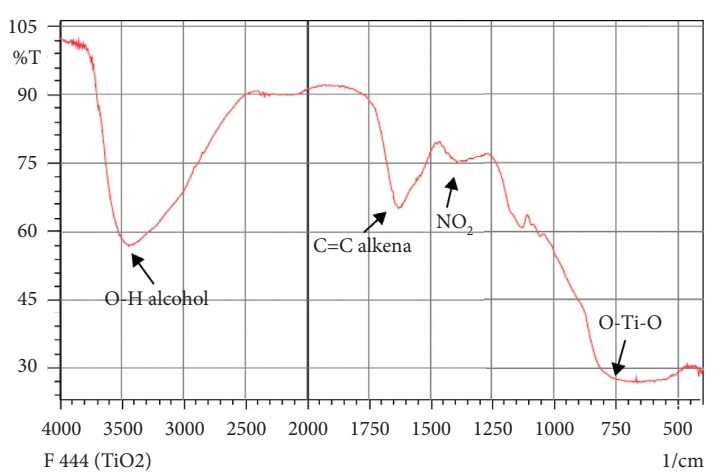

(a)

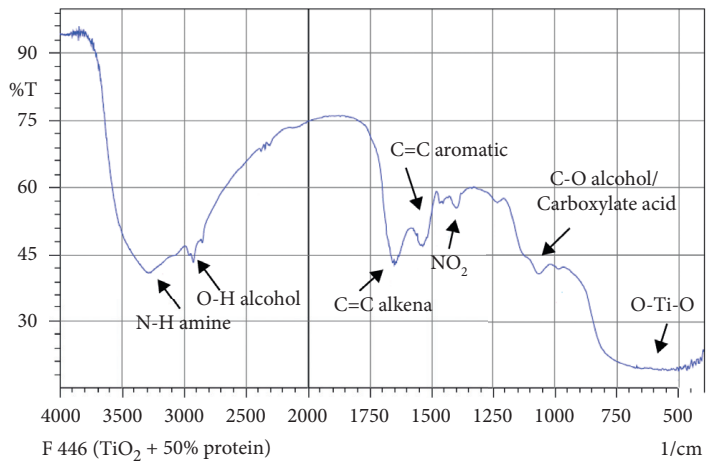

(c)

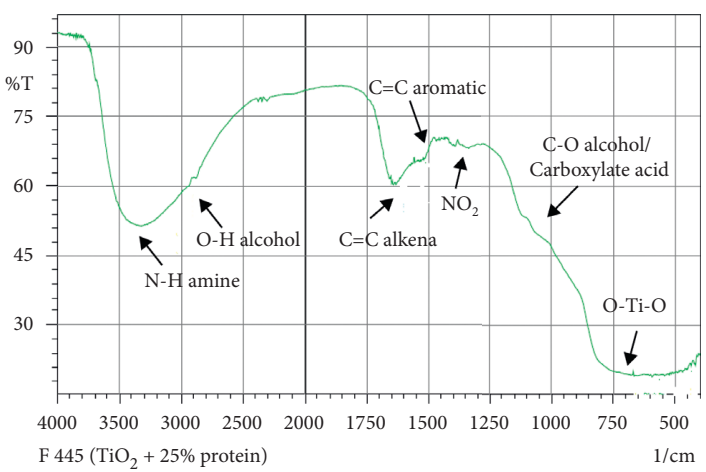

(b)

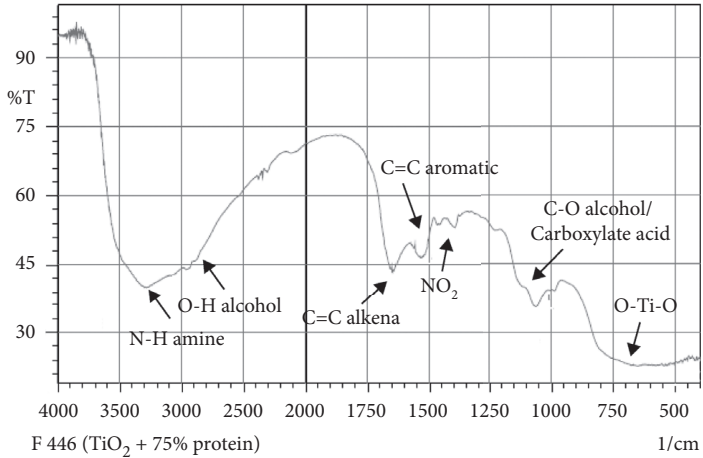

(d)

FIGURE 7: FTIR testing results on each cow brain protein concentration (\%). (a) 0, (b) 25, (c) 50, and (d) 75.

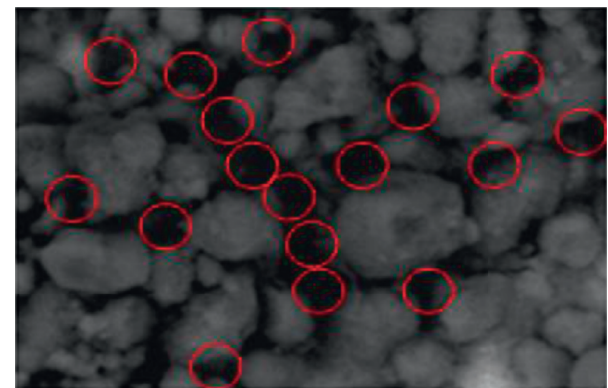

$2017 / 12 / 22$

$\mathrm{TiO}_{2}+$ dye

(a)

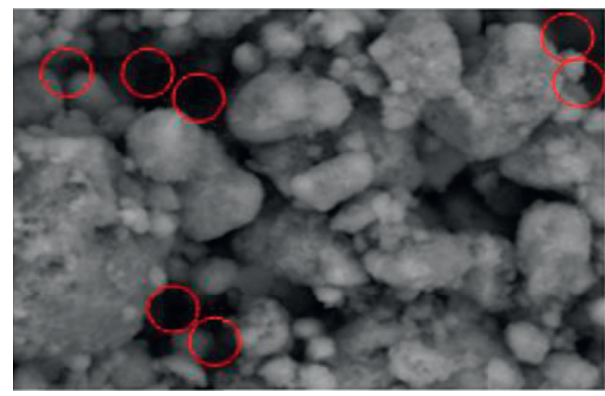

2018/01/02

$\mathrm{TiO}_{2}+$ dye + clathrin $50 \%$

(c)

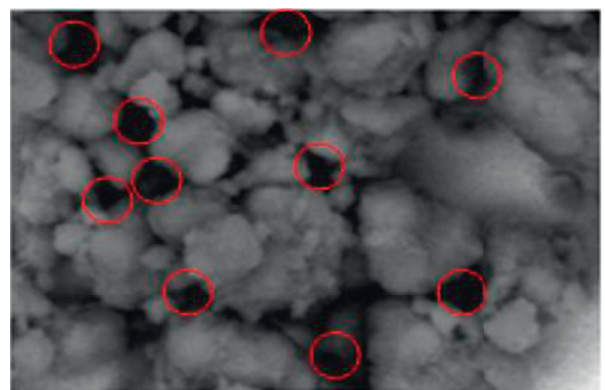

$2017 / 12 / 22$

$\mathrm{TiO}_{2}+$ dye + clathrin $25 \%$

(b)

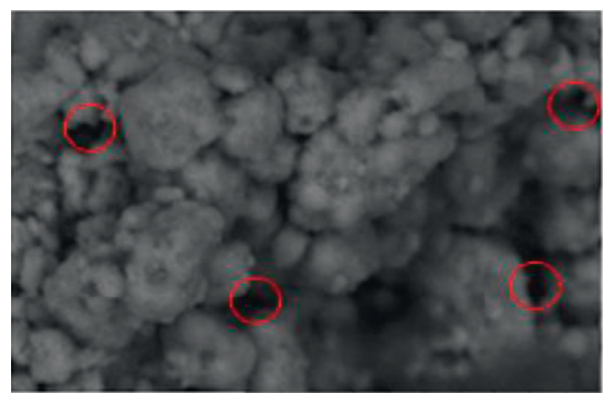

2018/01/02

$\mathrm{TiO}_{2}+$ dye + clathrin $75 \%$

(d)

FIgURE 8: DSSC morphology of 5000x magnification for each clathrin percentage (\%) (a) 0, (b) 25, (c) 50, and (d) 75. 
that the concentration of additional molecules of protein deposited into $\mathrm{TiO}_{2}$ increases, and the cavity or pore between the $\mathrm{TiO}_{2}$ molecules decreases; this can be seen by the decreasing portion of the dark area. The reduction of cavities in the layers indicates that protein molecules fill cavities that exist between $\mathrm{TiO}_{2}$ molecules.

The addition of clathrin that fills the gap between $\mathrm{TiO}_{2}$ particles can improve connectivity between $\mathrm{TiO}_{2}$ particles and produce closer contact of the semiconductor oxide, thereby accelerating the transfer of charge in the photoanode. Increased connectivity between $\mathrm{TiO}_{2}$ particles causes a reduction in electron flow resistance and creates a short path of electron flow, thereby reducing the possibility of recombination, and can increase DSSC efficiency. The presence of deposited molecules derived from these proteins serves as a bridge of electron transport to the anode becoming faster because proteins are electrolyte. The electrolytic character of proteins is due to the constitution making up of proteins, because protein molecules contain over 200 amino acid residues or more condensed into long polypeptide chains. Protein as an electrolyte is amphoteric that can act as a cation or anion. The zwitterions effect of proteins is that proteins can carry both positive and negative charges at the same time. Cations can join proteins if anionic-charged proteins are in an alkaline state while anions can join proteins if cationic-charged proteins are in an acidic state [30]. The presence of this electron bridge causes many interconnected molecules to facilitate faster electron transport so as to reduce recombination and improve DSSC performance.

3.4. Efficiency Testing. Testing of electrical current and voltage aims to determine changes in efficiency that occur after an increase in the concentration of cow brain protein by $0 \%, 25 \%, 50 \%$, and $75 \%$ on DSSC. Testing of electric current, voltage, and efficiency on DSSC with the addition of cow brain protein of $0 \%, 25 \%, 50 \%$, and $75 \%$ was done by measuring changes in electric current and voltage that occur under a beam of $1000 \mathrm{~W} / \mathrm{m}^{2}$ halogen lamps. The results of testing electric current, voltage, and efficiency for each additional concentration of bovine brain protein are presented in Table 3.

From Table 3, it can be seen that the increase in the concentration of cow brain protein added to DSSC causes an increase in the resulting efficiency. The highest efficiency value on DSSC was the addition of $75 \%$ protein concentration with $1.465 \%$ efficiency value.

The increase in the value of efficiency in DSSC is due to the cow brain protein molecule added to DSSC which fills the gaps or empty spaces in $\mathrm{TiO}_{2}$ because the clathrin protein derived from cow brain is zwitterions that is able to act as an electron bridge between porous $\mathrm{TiO}_{2}$ particles so as to reduce obstacles from the flow of electric current resulting in increased efficiency [31]. Electron bridges are able to occur because of the ability of proteins to do both acid and base reactions at once.

As one type of protein, clathrin is composed of various amino acids. According to Lewis's theory, amino acids are
TABLE 3: Electric current, voltage, and efficiency at each concentration of cow brain protein testing results.

\begin{tabular}{lcccccc}
\hline $\begin{array}{l}\text { DSSC } \\
(\%)\end{array}$ & $\begin{array}{c}\text { Isc } \\
(\mathrm{mA})\end{array}$ & $\begin{array}{c}\text { Voc } \\
(\mathrm{mV})\end{array}$ & $\begin{array}{c}\mathrm{Im} \\
(\mathrm{mA})\end{array}$ & $\begin{array}{c}\text { Vm } \\
(\mathrm{mV})\end{array}$ & $\mathrm{FF}$ & $\eta(\%)$ \\
\hline 0 & 0.353 & 562 & 0.161 & 293 & 0.238 & 0.047 \\
25 & 0.917 & 590 & 0.608 & 269 & 0.302 & 0.164 \\
50 & 2.643 & 624 & 1.368 & 377 & 0.313 & 0.516 \\
75 & 5.247 & 657 & 3.836 & 382 & 0.425 & 1.465 \\
\hline
\end{tabular}

able to conduct electrons [32]. Amino acids are compounds making up proteins. Amino acids have one carboxyl group and one amino group. In general, the amino group is bound to the position of the carboxyl group. Amino acids are able to act as acids (donating protons to strong bases) and to act as bases (receiving protons from strong acids).

According to the Lewis acid base theory, what is meant by Lewis acid is a compound that is able to accept electron pairs from other compounds, or electron pair acceptors, while Lewis bases are compounds that are able to render electron pairs to other compounds or donor electron pairs.

Lewis Acid Base Theory example is as follows.

In Figure 9, it is shown that, in the $\mathrm{H}^{+}$and $\mathrm{NH}_{3}$ reactions, the $\mathrm{H}^{+}$ion is a Lewis acid because it is able to accept electron pairs, whereas $\mathrm{NH}_{3}$ is a Lewis base. In the reaction between $\mathrm{BF}_{3}$ and $\mathrm{NH}_{3}, \mathrm{BF}_{3}$ is Lewis acid because it is able to accept a pair of electrons, while $\mathrm{NH}_{3}$ is a Lewis base.

Amino acids are compounds that consist of one or more carboxyl groups $(-\mathrm{COOH})$ and one or more amino groups $\left(-\mathrm{NH}_{2}\right)$, one of which is located on the $\mathrm{C}$ atom right next to the carboxyl group (C alpha atom). Amino acids combine through peptide bonds, which are bonds between carboxyl groups of amino acids and amino groups of amino acids that are next to it, as shown in Figure 10 [33].

The presence of unrestrained amino and carboxyl groups at the ends of a chain of protein molecules causes proteins to have a lot of charge and be amphoteric (able to react with acids or bases). In an acid solution, the amino group reacts with $\mathrm{H}^{+}$; accordingly, the protein is positively charged. When this condition is carried out, electrolysis, protein molecules will move towards the cathode. And conversely, in alkaline solutions protein molecules will react as acids or negatively charged; hence, protein molecules will move towards the anode as shown in Figure 11 [34].

The functional groups structurizing amino acids are able to enhance the electron transfer process in the DSSC layer since amino acids are amphoteric that are able to act as acids (donating protons to strong bases) and act as bases (receiving protons from strong acids) [22]. Amino acids are compounds making up proteins. Amino acids have one carboxyl group and one amino group.

Amino acids in the form of zwitterion, i.e., carboxyl groups in amino acids, are able to release hydrogen ions to be negatively charged and amine groups are able to receive hydrogen ions to be positively charged.

Figure 12 explains the phenomenon that occurs in the gap or empty space between $\mathrm{TiO} 2$ molecules that have been filled with clathrin protein; that is, when electrons flow from chlorophyll, they will be captured by clathrin protein 


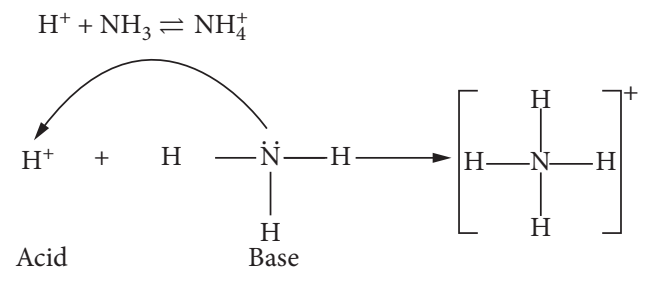

$\mathrm{BF}_{3}+\mathrm{NH}_{3} \rightleftharpoons \mathrm{NH}_{3} \mathrm{BF}_{3}$

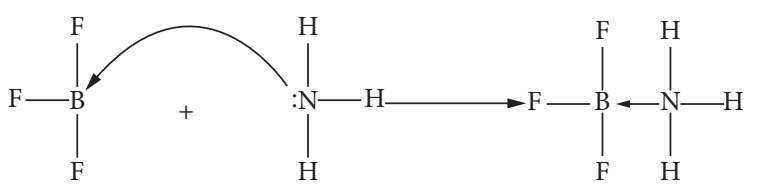

FIgURE 9: Lewis acid base theory [32].<smiles>[R]C(NC(=O)O)C(=O)O</smiles>

Figure 10: Amino acids structure [33].

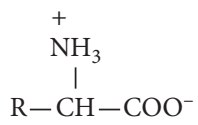

FIgURE 11: Zwitterion structure of amino acids [34].

molecules through an acidic reaction, and in this acidic state, the protein will donate protons to the base; hence, the protein tends to contain electrons and is eligible to be considered as negative poles (anodes), whereas in base reactions, proteins will receive protons from acids so proteins tend to contain protons and are eligible to be considered as positive poles (cathodes). In this state, electrons will flow from acids to bases. Through an alkaline reaction, the electrons will be released into $\mathrm{TiO} 2$; hence, the electron flow from chlorophyll to $\mathrm{TiO}_{2}$ will pass through the clathrin protein electron bridge. Accordingly, the electrons are able to go through all the pathways between $\mathrm{TiO}_{2}$ particles and increase the electric current in DSSC.

Comparison of the characteristics of DSSC test results of electric current and voltage for each concentration of cow brain protein addition is presented in Figure 13.

From Figure 13, it appears that the addition of clathrin concentration causes the short circuit current (Isc) and the open circuit voltage (Voc) to increase. This increase in current and voltage will result in an increase in DSSC efficiency. Yet, the movement of electrons in the $\mathrm{TiO}_{2}$ layer towards the electrodes causes a decrease in current due to the higher resistance caused by the distance travelled by electrons also getting farther away in the $\mathrm{TiO}_{2}$ layer which is getting thicker.

Figure 14 illustrates the mechanism of DSSC without clathrin and DSSC with clathrin. In the DSSC mechanism without clathrin, it appears that electrons flowing in the $\mathrm{TiO}_{2}$

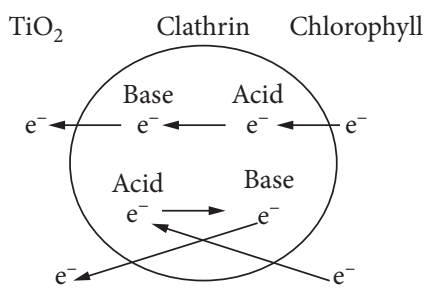

Figure 12: Zwitterion phenomenon on gap between $\mathrm{TiO}_{2}$.

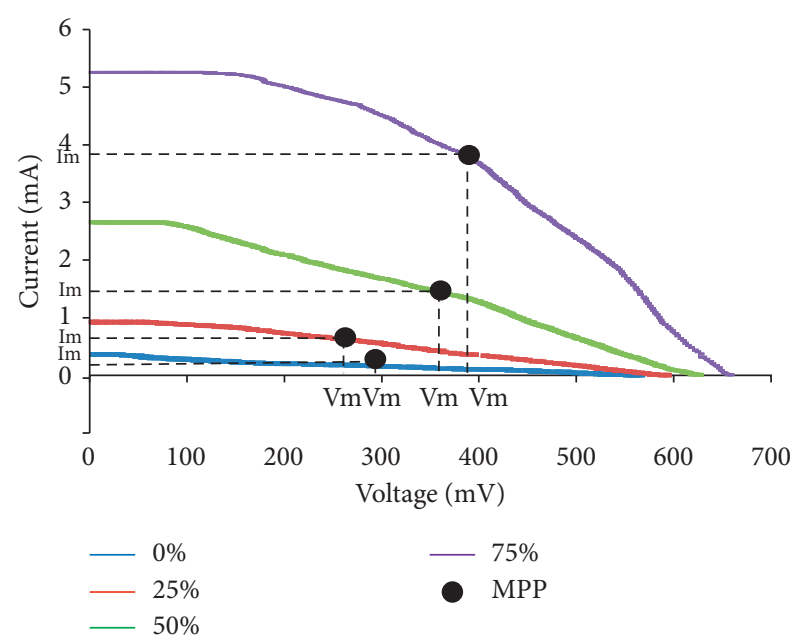

Figure 13: Comparison of electric current and voltage at each protein concentration.

conduction area are able to only flow through interconnected $\mathrm{TiO}_{2}$ particles; hence, the electron pathway is longer and the possibility of recombining electrons with oxidized dyes is greater, whereas in the DSSC mechanism with the addition of clathrin, it appears that the clathrin added fills the gap or empty space between the $\mathrm{TiO}_{2}$ particles; accordingly, the electron path in the $\mathrm{TiO}_{2}$ conduction area is shorter and the electrons are able to pass through all parts of the $\mathrm{TiO}_{2}$ particle and cause internal resistance to electron flow to decrease and the possibility of electron recombination with dye oxidation decreases which results in an increase in DSSC efficiency.

In conventional DSSC, there are gaps or empty spaces at the grain boundary of the combined $\mathrm{TiO}_{2}$ molecules. These gaps or empty spaces cause obstacles from electron transport injected into the $\mathrm{TiO}_{2}$ semiconductor. Due to the resistance of the internal resistance to $\mathrm{TiO} 2$, this electron diffusion is inhibited, resulting in a higher chance of recombining electrons to dye and electrolytes. It is illustrated in Figure 15.

In the DSSC added with clathrin, clathrin molecules have the ability to self-assemble and to wrap particles, and the combining clathrin molecules around $30-100 \mathrm{~nm}$ in size will wrap around $\mathrm{TiO}_{2}$ about $11-20 \mathrm{~nm}$ in size and fill gaps or empty spaces between grain boundaries of $\mathrm{TiO}_{2}$. Accordingly, it reduces internal resistance and generates maximum electron transport. The flow of electrons and the molecular structure of the layer after the addition of clathrin is illustrated in Figure 16. 


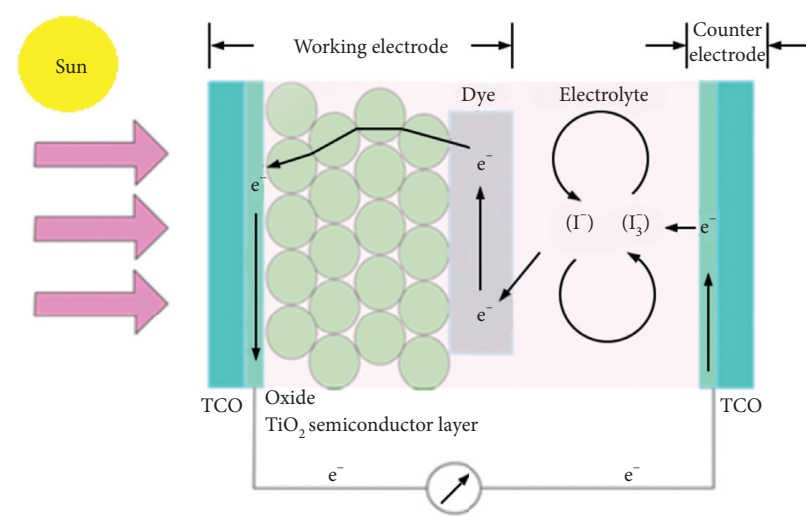

(a)

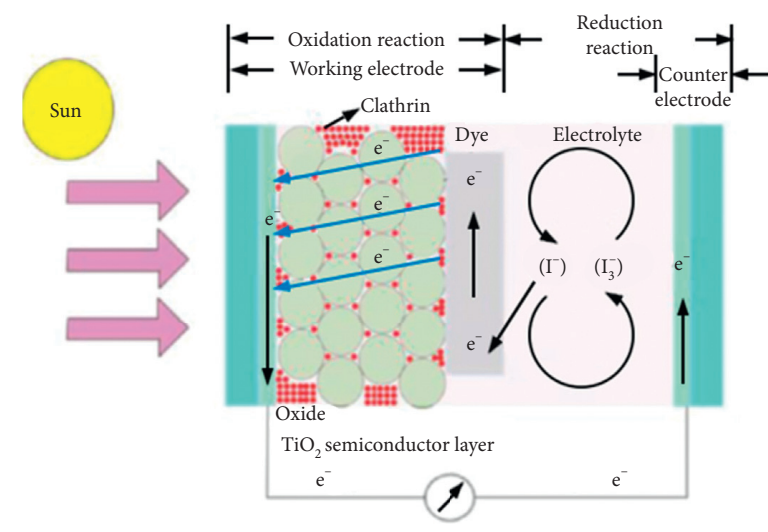

(b)

FIGURE 14: Electrons flows mechanism on DSSC. (a) DSSC without clathrin. (b) DSSC with clathrin.

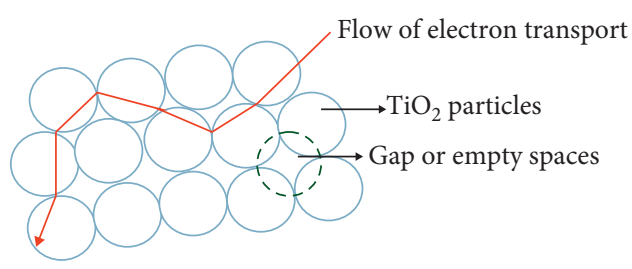

FIGURE 15: Internal resistance on conventional DSSC [11].

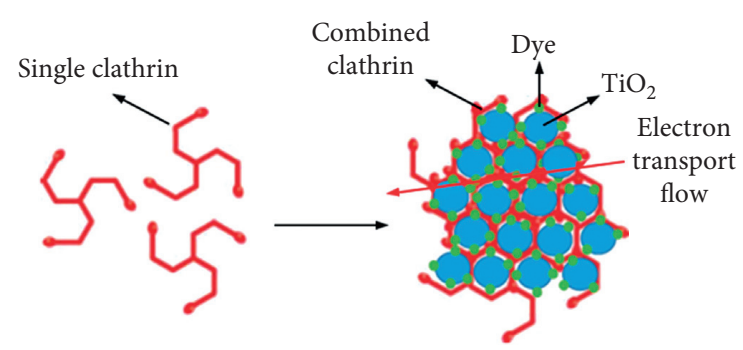

FIGURE 16: Electron flows and DSSC molecules structure of DSSC added with clathrin.

\section{Conclusion}

According to the results and discussion explained above, this research presents several conclusions as follows:

(1) The addition of cow brain protein forms amino acid constituent functional groups in DSSC in the form of the emergence of $\mathrm{N}-\mathrm{H}$ compounds Amine, O-H, Alkene, Aromatic, NO2 nitro compounds, and C-O Alcohol/Acid, while amino acids are compounds making up proteins.

(2) The more concentration of cow brain protein on DSSC indicates the steeper absorption at the transmittance rate of the wave numbers in the FTIR spectrum. The steeper uptake indicates the greater energy absorbed by the functional group formed by the increasing concentration of cow brain protein in DSSC.

(3) When the number of concentrations of additional molecules of proteins deposited into $\mathrm{TiO}_{2}$ is increasing, the cavity or pore between the existing $\mathrm{TiO}_{2}$ molecules decreases. The reduction of cavities in the layers indicates that protein molecules fill cavities that exist between $\mathrm{TiO}_{2}$ molecules. The addition of clathrin that fills the gap between $\mathrm{TiO}_{2}$ particles can improve connectivity between $\mathrm{TiO}_{2}$ particles and produce closer contact of the semiconductor oxide, thereby accelerating the transfer of charge in the photoanode.

(4) An increase in the concentration of cow brain protein added increases DSSC efficiency. The highest efficiency value on DSSC is the addition of $75 \%$ protein concentration with $1.465 \%$ efficiency value.

(5) The efficiency value increase on DSSC is due to the cow brain protein molecule added to DSSC which fills a gap or empty space in $\mathrm{TiO}_{2}$. Cow brain protein contains zwitterion properties that is able to act as electron bridges between porous $\mathrm{TiO}_{2}$ particles; accordingly, it is capable of reducing the resistance of the flow of electric current and increasing efficiency produced.

\section{Data Availability}

The data used to support the findings of this study are available from the corresponding author upon request.

\section{Conflicts of Interest}

The authors declare that they have no conflicts of interest.

\section{Acknowledgments}

This research was funded by doctoral research grant for the associate professor of Brawijaya University 2019 (no. 16/ UN10.F07/PN/2019).

\section{References}

[1] M. B. Askari, A. V. Mirzaei Mahmoud, and M. Mohsen, "Types of solar cells and application," American Journal of Optics and Photonics, vol. 3, no. 5, pp. 94-113, 2015.

[2] T.-W. Lin, J.-R. Lin, S.-Y. Tsai, and C.-C. Ting, "Absorption spectra analysis of natural dyes for applications in DyeSensitized Nano Solar Cells," in Proceedings of the 31st 
National Conference on Theoretical and Applied Mechanics, ISU, Kaohsiung, Taiwan, December 2007.

[3] B. O’Regan and M. Gratzel, "A low-cost, high-efficiency solar cell based on dye-sensitized colloidal $\mathrm{TiO}_{2}$ films," Nature, vol. 353, pp. 737-740, 1991.

[4] M. R. Narayan, "Review: dye-sensitized solar cells based on natural photosensitizers," Renewable and Sustainable Energy Reviews, vol. 6, pp. 208-215, 2011.

[5] M. K. Nazeeruddin, A. Kay, I. Rodicio et al., "Conversion of light to electricity by cis-X2bis (2,2'-bipyridyl-4,4'-dicarboxylate) ruthenium (II) charge-transfer sensitizers (X= Cl-, $\mathrm{Br}-, \mathrm{I}-, \mathrm{CN}-$, and $\mathrm{SCN}-$ ) on nanocrystalline titanium dioxide electrodes," Journal of the American Chemical Society, vol. 115, no. 14, pp. 6382-6390, 1993.

[6] M. Grätzel, "Dye-sensitized solar cells," Journal of Photochemistry and Photobiology C: Photochemistry Reviews, vol. 4, no. 2, pp. 145-153, 2003.

[7] Y. Zhou, Organic-inorganic Hybrid Solar Cells: State of the Art, Challenges and Perspectives, Solar Cells-New Aspects and Solutions, P. L. A. Kosyachenko, Ed., InTech, London, UK, 2011.

[8] Z. Arifin, S. Soeparman, D. Widhiyanuriyawan, and S. Suyitno, "Performance enhancement of dye-sensitized solar cells using a natural sensitizer," International Journal of Photoenergy, vol. 2017, Article ID 2704864, 5 pages, 2017.

[9] X.-F. Wang, C.-H. Zhan, T. Maoka, Y. Wada, and Y. Koyama, "Fabrication of dye-sensitized solar cells using chlorophylls c1 and c2 and their oxidized forms," Chemical Physics Letters, vol. 447, no. 1-3, pp. 79-85, 2007.

[10] M. K. Nazeeruddin, E. Baranoff, and M. Gratzel, "Dye-Sensitized solar cells: a brief overview," Solar Energy, vol. 85, pp. 1172-1178, 2011.

[11] J. Yu, D. Wang, Y. Huang et al., "A cylindrical core-shell-like $\mathrm{TiO}_{2}$ nanotube array anode for flexible fiber-type Dye-Sensitized Solar Cell," Nanoscale Research Letters, vol. 6, no. 94, pp. 1-9, 2011.

[12] H. Hu, J. Shen, X. Cao et al., "Photo-assisted deposition of Ag nanoparticles on branched $\mathrm{TiO}_{2}$ nanorod arrays for DyeSensitized Solar Cells with enhanced efficiency," Journal of Alloys and Compounds, vol. 694, pp. 653-661, 2016.

[13] R. K. Chava and M. Kang, "Improving the photovoltaic conversion efficiency of $\mathrm{ZnO}$ based Dye-Sensitized Solar Cells by indium doping," Journal of Alloys and Compounds, vol. 692, pp. 67-76, 2017.

[14] S. C. Chou, Y. C. Chen, H. S. Lin, H. W. Lu, and P. Wu, "Preparation of $\mathrm{TiO}_{2}$ /bamboo- charcoal-powder composite particles and their applications in Dye-Sensitized Solar Cells," Advanced Powder Technology, vol. 26, no. 3, pp. 711-717, 2015.

[15] D. Kuang, C. Klein, J. H. Snaith et al., "Ion coordinating sensitizer for high efficiency mesoscopic Dye-Sensitized Solar Cells: influence of lithium ions on the photovoltaic performance of liquid and solid-state cells," Nano Letter, vol. 6, no. 4, pp. 769-773, 2006.

[16] B. Pearse, "Clathrin: a unique protein associated with intracellular transfer of membrane by coated vesicles," Proceedings of the National Academy of Sciences, vol. 73, no. 4, pp. 1255-1259, 1976.

[17] M. G. Ford, B. M. Pearse, M. K. Higgins et al., "Simultaneous binding of PtdIns $(4,5)$ P2 and Clathrin by AP180 in the nucleation of Clathrin lattices on membranes (PDF)," Science, vol. 291, no. 5506, pp. 1051-1055, 2001.

[18] P. N. Dannhauser, M. Platen, H. Böning, and I. A. T. Schaap, "Durable protein lattices of clathrin that can be functionalized with nanoparticles and active biomolecules," Nature Nanotechnology, vol. 10, no. 11, pp. 954-957, 2015.

[19] A. P. Schoen, D. T. Schoen, K. N. L. Huggins, M. A. Arunagirinathan, and S. C. Heilshorn, "Template Engineering through Epitope Recognition: a modular, biomimetic strategy for inorganic nanomaterial synthesis," Journal of the American Chemical Society, vol. 133, no. 45, pp. 18202-18207, 2011.

[20] D. Templeton, Molecular and Cellular Iron Transport, Marcel Dekker, New York, NY, USA, 2002.

[21] P. Trihutomo, S. Soeparman, W. Denny, and L. Yuliati, "Performance improvement of dye-sensitized solar cell (DSSC) based natural dyes by clathrin protein," International Journal of Photoenergy, vol. 2019, Article ID 4384728, 9 pages, 2019.

[22] S. P. Lin, Amino Acids and Proteins, Institute of Biomedical Engineering, National Chung Hsing University, Taiwan, China, 2010.

[23] A. T. Vu, Q. T. Nguyen, T. H. L. Bui, M. C. Tran, T. P. Dang, and T. Kim Hoa Tran, "Synthesis and characterization of $\mathrm{TiO}_{2}$ photocatalyst doped by transition metal ions $\left(\mathrm{Fe}^{3+}, \mathrm{Cr}^{3+}\right.$, and $\left.\mathrm{V}^{5+}\right)$," Advances in Natural Sciences: Nanoscience and Nanotechnology, vol. 1, no. 1, Article ID 015009, 2010.

[24] M. Toyoda, "Effect of cristallinity of anatase on photoactivity methyleneblue decomposition in water," Applied Catalysis B: Environmental, vol. 49, no. 4, pp. 227-232, 2004.

[25] E. Purushotham and N. G. Krishna, "X-ray determination of crystallite size and effect of lattice strain on Debye-Waller factors of platinum nano powders," Bulletin of Materials Science, vol. 36, no. 6, pp. 973-976, 2013.

[26] D. A. Skoog, F. J. Holler, S. R. Crouch, and R. S, Principles of Instrumental Analysis, Thomson Brooks/Cole, Boston, MA, USA, 6th edition, 2007.

[27] R. W. Thatcher, The Chemistry of Plant Life, McGraw-Hill Book Company, New York, NY, USA, 1st edition, 1921.

[28] J. Coates, Interpretation of Infrared Spectra, A Practical Approach, John Wiley \& Sons Ltd., Hoboken, NJ, USA, 2006.

[29] S. Lee, P. Y. Chang, Y. L. Lee, and F. J. Hsu, Characterization of Dye-Sensitized Solar Cell with $\mathrm{ZnO}$ Nanorod Multilayer Electrode, National Kaohsiung University of Applied Sciences, Kaohsiung, Taiwan, 2007.

[30] J. D. Lloyd, The Proteins as Colloidal Electrolytes, Northeastern University, Boston, MA, USA, 1934.

[31] P. Trihutomo, S. Soeparman, W. Denny, and L. Yuliati, "Role of clathrin protein to increase electric current on dye-sensitized solar cell (DSSC) based natural dyes," IOP Conference Series: Materials Science and Engineering, vol. 546, Article ID 072010, , 2019.

[32] G. L. Miessler and D. A. Tarr, Inorganic Chemistry, Pearson Prentice-Hall, Upper Saddle River, NJ, USA, 2nd edition, 1991.

[33] J. A. Cozzone, Proteins: Fundamental Chemical Properties, Encyclopedia of Life Sciences, Macmillan Publishers Ltd, Nature Publishing Group, New York, NY, USA, 2002.

[34] H. Eckweiler, M. H. Noyes, and K. G. Falk, "The amphoteric properties of some amino-acids and peptides," The Journal of General Physiology, vol. 3, no. 3, pp. 291-308, 1921. 